\title{
Classic neuroendocrine tumor of appendix
}

INSERM

\section{Source}

INSERM. (1999). Orphanet: an online rare disease and orphan drug data base. Classic neuroendocrine tumor of appendix. ORPHA:329977

Classic endocrine tumor of the appendix is a type of endocrine tumor of the appendix (see this term), seen twice as frequently in females than in males, and usually presenting before the fifth decade of life. Classic endocrine tumor of the appendix is usually asymptomatic when located in the tip of the appendix (without obstruction), but acute appendicitis is often associated. 